\title{
Testing of an lodine and Tritium Removal System for Advanced Tritium Pretreatment Off-Gas
}

\section{Nuclear Technology}

Research and Development

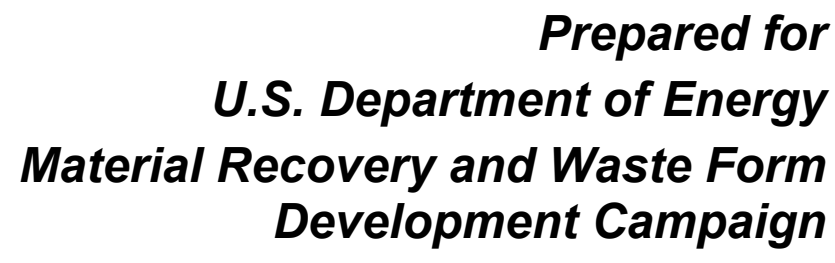

R. T. Jubin, J. A. Jordan, S. H. Bruffey

Oak Ridge National Laboratory

31 January 2018 NTRD-MRWFD-2018-000199 ORNL/SPR-2018/15 



\section{DISCLAIMER}

This information was prepared as an account of work sponsored by an agency of the U.S. Government. Neither the U.S. Government nor any agency thereof, nor any of their employees, makes any warranty, expressed or implied, or assumes any legal liability or responsibility for the accuracy, completeness, or usefulness, of any information, apparatus, product, or process disclosed, or represents that its use would not infringe privately owned rights. References herein to any specific commercial product, process, or service by trade name, trade mark, manufacturer, or otherwise, does not necessarily constitute or imply its endorsement, recommendation, or favoring by the U.S. Government or any agency thereof. The views and opinions of authors expressed herein do not necessarily state or reflect those of the U.S. Government or any agency thereof. 



\section{SUMMARY}

The reprocessing of used nuclear fuel would release volatile radionuclides into the off-gas of a processing plant, including ${ }^{3} \mathrm{H},{ }^{14} \mathrm{C},{ }^{85} \mathrm{Kr}$, and ${ }^{129} \mathrm{I}$. For a reprocessing plant sited within the United States and governed by US regulations, the abatement of some or all of these radionuclides from the plant off-gas would be required before discharge of that gas to the environment.

A potential simplification of the off-gas management system can be achieved through an efficient advanced tritium pretreatment (ATPT) step in which the $\mathrm{UO}_{2}$ fuel is oxidized by $\mathrm{NO}_{2}$ prior to dissolution. Oxidation of the $\mathrm{UO}_{2}$ fuel matrix results in the release of tritium contained within. Up-front removal of tritium from the fuel in a pretreatment step, followed by the abatement of tritium from the advanced tritium pretreatment off-gas (ATPTOG) stream, can minimize or eliminate the distribution of tritium throughout the plant, also decreasing or eliminating the need for tritium capture on multiple off-gas streams. The use of $\mathrm{NO}_{2}$ as the oxidant allows tritium pretreatment to be performed at lower temperatures and may result in the quantitative release of iodine from the fuel.

The ATPTOG will contain up to 75 vol\% $\mathrm{NO}_{2}$ gas. In a previous report, Spencer et al. (2017) identified the most promising iodine sorbent as silver nitrate-impregnated alumina (AgA) and the most promising tritium sorbents as 3A molecular sieve (3A MS) and silica gel for radionuclide capture from ATPTOG streams. Jubin et al. (2017) documented the preliminary testing of those sorbents for iodine and tritium removal from ATPTOG streams, while this report describes the results from both that testing and selected follow-on testing.

A total of five tests examined $\mathrm{AgA}$ as a potential iodine sorbent at an operating temperature of $150^{\circ} \mathrm{C}$ and both $3 \mathrm{~A} \mathrm{MS}$ and silica gel as potential tritium sorbents with an operating temperature of $40^{\circ} \mathrm{C} .3 \mathrm{~A} \mathrm{MS}$ and silica gel are intended for use as regenerative sorbents, in which the adsorbed tritium (as tritiated water or tritiated nitric acid) is loaded onto the sorbent at operating temperature and then subsequently desorbed at high temperature into a small-volume gas stream for recovery and conversion to a waste form.

Analysis of the test materials showed that much of the tritium and iodine delivered during testing was not recovered on the solid sorbent test materials or liquid scrubbers used in test execution. The cause of this discrepancy was identified during system disassembly, in which a system component was found to be corroded. Analysis of the corroded component found that it contained both iodine and tritium. The loss of tritium and iodine to the test system negatively impacted the ability to draw quantitative conclusions regarding the adsorption of tritium by either silica gel or $3 \mathrm{~A}$ MS in high $\mathrm{NO}_{2}$ systems. Residual tritium was found on both the iodine and tritium sorbents at the end of each test.

The ability of AgA to adsorb iodine in the presence of high levels of $\mathrm{NO}_{2}$ appears to be substantially reduced upon exposure of the sorbent to $\mathrm{NO}_{2}$, with replicate testing showing variable iodine recoveries on the sorbent of $29.6 \%$ and $<0.1 \%$. Given the corrosion observed during testing, the performance of AgA should be reexamined with a more robust system. These initial tests, however, do indicate a failure of the sorbent to perform to the levels that would be required in an ATPTOG treatment system.

This testing leaves many fundamental questions regarding the ATPTOG iodine and tritium abatement systems unanswered. These include questions regarding sorbent capacity and sorbate desorption. Overall, this testing indicates that tritium and iodine abatement from an ATPTOG stream by solid sorbents is currently at a low stage of technological development and that deployment of such an abatement system would require substantial additional research and development. 
This page is intentionally left blank. 


\section{CONTENTS}

\section{SUMMARY}

\section{CONTENTS}

FIGURES

TABLES

\section{ACRONYMS}

1. INTRODUCTION

2. TEST DESCRIPTIONS

3. MATERIALS AND METHODS

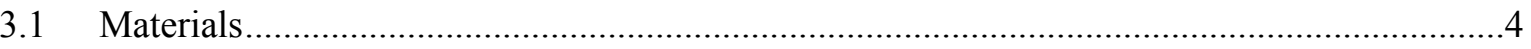

3.2 Establishment of Recirculation Loop and Iodine Capture Phase ...........................................

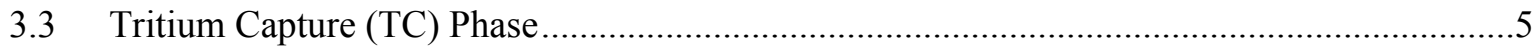

3.4 Tritium Sorbent Regeneration (TR) Phase ......................................................................6

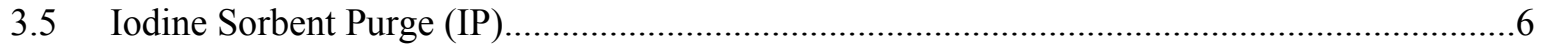

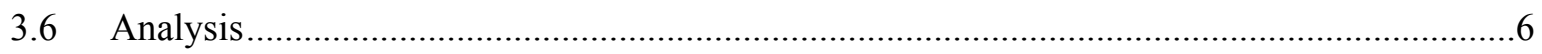

4. RESULTS

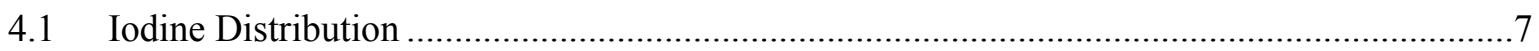

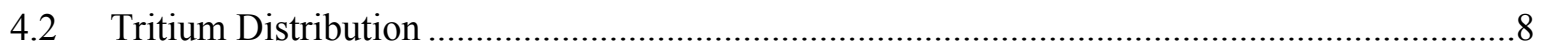

5. SYSTEM DISASSEMBLY

6. CONCLUSIONS

7. REFERENCES 
This page is intentionally left blank. 


\section{FIGURES}

Figure 1: Schematic of iodine and tritium sorbent test system............................................................

Figure 2: Photograph of iodine and tritium sorbent test system. ...........................................................

Figure 3: Gas flow path (bolded) during iodine capture phase ..................................................................

Figure 4: Gas flow path (bolded) during tritium capture phase...............................................................5

Figure 5: Gas flow path (bolded) during tritium regeneration phase........................................................6

Figure 6: Gas flow path (bolded) during iodine sorbent purge phase......................................................6

\section{TABLES}

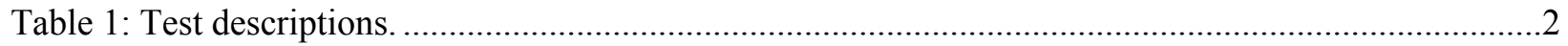

Table 2: Tritium and iodine recovered from ATPTOG test system. …...............................................

Table 3: Iodine distribution between AgA bed segments and liquid scrubbers, Test 2 ............................

Table 4: Iodine distribution between AgA bed segments and liquid scrubbers, Test 3 .............................8

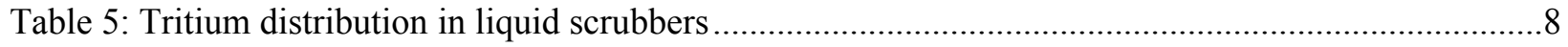


This page is intentionally left blank. 


\section{ACRONYMS}

$\begin{array}{ll}\text { 3A MS } & \text { 3 angstrom molecular sieve } \\ \text { AgA } & \text { AgNO }_{3} \text {-impregnated alumina } \\ \text { ATPTOG } & \text { advanced tritium pretreatment off-gas } \\ \text { DOG } & \text { dissolver off-gas } \\ \text { ICP-MS } & \text { inductively coupled plasma-mass spectrometry } \\ \text { IP } & \text { iodine sorbent purge } \\ \text { LPM } & \text { liters per minute } \\ \text { LSC } & \text { liquid scintillation counting } \\ \text { MDA } & \text { minimum detectable activity } \\ \text { NAA } & \text { neutron activation analysis } \\ \text { ORNL } & \text { Oak Ridge National Laboratory } \\ \text { TC } & \text { tritium capture } \\ \text { TR } & \text { tritium sorbent regeneration } \\ \text { TPTOG } & \text { tritium pretreatment off-gas } \\ \text { TPT } & \text { tritium pretreatment }\end{array}$


This page is intentionally left blank. 


\section{TESTING OF AN IODINE AND TRITIUM REMOVAL SYSTEM FOR ADVANCED TRITIUM PRETREATMENT OFF-GAS}

\section{INTRODUCTION}

The reprocessing of used nuclear fuel will release four volatile radionuclides into the off-gas of a processing plant. These radionuclides are ${ }^{3} \mathrm{H},{ }^{14} \mathrm{C},{ }^{85} \mathrm{Kr}$, and ${ }^{129} \mathrm{I}$. For a reprocessing plant sited within the United States and governed by US regulations, the abatement of some or all of these radionuclides from the plant off-gas will be required before discharge of that gas to the environment. In some cases, the level of abatement required is significant (Jubin et al., 2012).

Traditional aqueous reprocessing dissolves sheared used fuel in hot nitric acid solution. As the fuel dissolves, the volatile radionuclides contained within the fuel are evolved into the dissolver off-gas (DOG) stream. This off-gas contains, in addition to the volatile radionuclides, several volume percent of $\mathrm{NO}_{\mathrm{x}}$ vapor and $\mathrm{H}_{2} \mathrm{O}$. There is also some proportion of the volatile radionuclides retained by the dissolver solution, and those radionuclides are transferred to subsequent processing steps and to the process off-gas generated by those processes. The distribution of the radionuclides into multiple liquid and gaseous streams results in the need to abate volatile radionuclides from multiple off-gas emission streams throughout the reprocessing plant.

A potential simplification of the off-gas management system can be achieved through an efficient tritium pretreatment (TPT) step in which the $\mathrm{UO}_{2}$ in the used fuel is oxidized prior to dissolution. Oxidation of the $\mathrm{UO}_{2}$ fuel matrix results in the release of tritium contained within. Traditional TPT is conducted by oxidizing the fuel with a dry $\mathrm{O}_{2}$-bearing gas stream at high temperatures. Upfront removal of tritium from the fuel in a pretreatment step, followed by the abatement of tritium from the TPT off-gas stream, can minimize or eliminate the distribution of tritium throughout the plant, also decreasing or eliminating the need for tritium capture on multiple off-gas streams.

An advanced variant of the $\mathrm{O}_{2}$-based TPT process utilizes $\mathrm{NO}_{2}$, a stronger oxidant, as the gaseous reagent. The use of $\mathrm{NO}_{2}$ allows TPT to be performed at lower temperatures and may result in the quantitative release of iodine from the fuel. Upfront removal and abatement of iodine and tritium could result in substantially further simplification of the off-gas treatment processes required in the United States. Oak Ridge National Laboratory (ORNL) has developed this technology at the kg-scale with unirradiated $\mathrm{UO}_{2}$ and is prepared to demonstrate the technology with irradiated fuel in ORNL hot cells (Johnson and DelCul, 2016).

The advanced tritium pretreatment off-gas (ATPTOG) will contain up to $75 \mathrm{vol} \% \mathrm{NO}_{2}$ gas. Given the highly oxidizing, corrosive, and toxic nature of $\mathrm{NO}_{2}$ gas, it is unknown how traditional iodine sorbents, such as silver-exchanged zeolites, and traditional tritium adsorbents, such as molecular sieves, will perform in the ATPTOG system.

A previous report (Spencer et al., 2017) identified the most promising iodine sorbent as silver nitrateimpregnated alumina $(\mathrm{AgA})$ and the most promising tritium sorbents as $3 \mathrm{~A}$ molecular sieve (3A MS) and silica gel for radionuclide capture from ATPTOG streams. The reaction between silver nitrate $\left(\mathrm{AgNO}_{3}\right)$ and $\mathrm{I}_{2}$ to form $\mathrm{AgI}$ is thermodynamically favorable, and minerals impregnated with $\mathrm{AgNO}_{3}$ have been used for $\mathrm{I}_{2}$ removal from DOG streams at the La Hague fuel reprocessing plant in France. However, the DOG stream contains only $\sim 2 \mathrm{vol} \% \mathrm{NO}_{\mathrm{x}}$ gaseous species, far below the levels expected in the ATPTOG stream. The preliminary testing of AgA, 3A MS, and silica gel for iodine and tritium removal from ATPTOG streams is documented in Assembly and Testing of a Tritium and Iodine Removal System for Use with Advanced Tritium Pretreatment, NTRD-MRWFD-2017-000157 (Jubin, et al. 2017). The intent of this 
report is to document the results of both the testing described by Jubin et al. (2017) and the results of selected follow-on testing.

\section{TEST DESCRIPTIONS}

A total of five tests were performed, and the details of each test are summarized in Table 1. Jubin et al. (2017) suggested an experimental test matrix that included a total of 10 tests. Because of a required relocation of the laboratory, only five of the selected tests from the proposed test matrix were completed. The test IDs provided in the initial report differ from the test IDs used here, and both test IDs are provided in Table 1 for ease of reference.

Table 1: Test descriptions.

\begin{tabular}{|c|c|c|c|c|c|c|c|}
\hline Test ID & $\begin{array}{l}\text { Previous } \\
\text { test Id } \\
(2017)\end{array}$ & $\begin{array}{c}\text { Iodine } \\
\text { sorbent }\end{array}$ & $\begin{array}{l}\text { Tritium } \\
\text { sorbent }\end{array}$ & $\begin{array}{c}\text { Tritium } \\
\text { sorbent } \\
\text { operating } \\
\text { temperature } \\
\left({ }^{\circ} \mathrm{C}\right)\end{array}$ & $\begin{array}{c}\text { Iodine } \\
\text { introduction }\end{array}$ & $\begin{array}{c}\text { Tritium bed } \\
\text { desorption } \\
\text { temperature } \\
\left({ }^{\circ} \mathrm{C}\right)\end{array}$ & Notes \\
\hline $\begin{array}{c}\text { ATPTOG- } \\
1\end{array}$ & ATPTOG-1 & $\mathrm{AgA}$ & None & N/A & None & N/A & $\begin{array}{c}\text { Establish } \\
\text { tritium/ethylene } \\
\text { glycol baseline }\end{array}$ \\
\hline $\begin{array}{c}\text { ATPTOG- } \\
2\end{array}$ & ATPTOG-2 & $\mathrm{AgA}$ & Silica gel & $40^{\circ} \mathrm{C}$ & Mid-Test & $90^{\circ} \mathrm{C}$ & \\
\hline $\begin{array}{c}\text { ATPTOG- } \\
3\end{array}$ & ATPTOG-3 & $\mathrm{AgA}$ & 3A MS & $40^{\circ} \mathrm{C}$ & Mid-Test & $250^{\circ} \mathrm{C}$ & \\
\hline $\begin{array}{c}\text { ATPTOG- } \\
4\end{array}$ & ATPTOG-6 & $\mathrm{AgA}$ & None & N/A & None & N/A & $\begin{array}{l}\text { Confirm } \\
\text { tritium/ethylene } \\
\text { glycol baseline }\end{array}$ \\
\hline $\begin{array}{c}\text { ATPTOG- } \\
5\end{array}$ & $\begin{array}{c}\text { ATPTOG- } \\
10\end{array}$ & None & None & N/A & None & N/A & $\begin{array}{c}\text { Determine } \\
\text { whether AgA } \\
\text { retains tritium }\end{array}$ \\
\hline
\end{tabular}

$\mathrm{AgA}$ was tested as a potential iodine sorbent at an operating temperature of $150^{\circ} \mathrm{C}$, and both $3 \mathrm{~A}$ MS and silica gel were tested as potential tritium sorbents with an operating temperature of $40^{\circ} \mathrm{C} .3 \mathrm{~A} \mathrm{MS}$ and silica gel are intended for use as regenerative sorbents, in which the adsorbed tritium (as tritiated water or tritiated nitric acid) is loaded onto the sorbent at operating temperature and then subsequently desorbed at high temperature into a small-volume gas stream for recovery and conversion to a waste form. The manufacturer-recommended desorption temperatures for $3 \mathrm{~A} \mathrm{MS}$ and silica gel are $>250^{\circ} \mathrm{C}$ and $>90^{\circ} \mathrm{C}$, respectively. 
In the operation of the test system, the system is first charged with an $\mathrm{NO}_{2} / \mathrm{O}_{2}$ gas mixture, and the recirculation loop is established. Following establishment of the recirculation loop, tritium and iodine can be introduced. Tritium was introduced as tritiated liquid water, and iodine was introduced as solid iodine crystals. An isolation lock for component introduction was designed such that a test port was opened, the material was introduced into a small load chamber, and the test port was closed. A second port was then opened connecting the load chamber to the recirculation loop. As the recirculation loop was at subatmospheric pressure, and the load chamber was heated, it was expected that both the crystalline iodine and liquid tritiated water would transfer into the gas recirculation loop quickly and completely.

The details and timing of iodine release from the fuel during the advanced tritium pretreatment process are not well known. Jubin et al. (2017) proposed two types of testing - one in which the iodine was introduced immediately upon establishment of the recirculation loop and the other in which the iodine was introduced after the recirculation loop had been in contact with the sorbent for 2 hours. The effect of $\mathrm{NO}_{2}$ on $\mathrm{AgA}$ sorbent is not well known, but previous tests have indicated that its iodine capture capacity decreases upon exposure to $\mathrm{NO}_{2}$ (Jordan et al., 2017). Introduction of iodine after some exposure of the sorbent to $\mathrm{NO}_{2}$ could provide an indication of $\mathrm{AgA}$ resistance to degradation by $\mathrm{NO}_{2}$. For each of the tests described here, iodine was introduced at the mid-point of the test ( 2 hours after establishment of the recirculation loop). Tritium was introduced immediately after the establishment of the recirculation loop.

As was recommended by Spencer et al. (2017), the tritium bed was bypassed during iodine adsorption. At the conclusion of testing, the gas stream was passed through the tritium bed and discharged into a series of ethylene glycol and caustic scrubbers. This was intended to simulate operations in which the tritium is allowed to build up to a maximum concentration during fuel oxidation, potentially improving adsorption of tritium from the gas stream upon discharge through the tritium sorbent bed. The scrubbers were used to assess the amount of tritium passing through the tritium sorbent bed.

As is shown in Table 1, ATPTOG-1 and ATPTOG-4 are replicate tests designed to assess the expected baseline tritium recovery when no tritium sorbent is present and to be used for comparison with tests in which the tritium sorbent is present. ATPTOG-2 and ATPTOG-3 served to test each tritium sorbent and provided replicate testing of the AgA iodine sorbent. Finally, ATPTOG-5, with no tritium or iodine sorbent emplaced, was intended for comparison with ATPTOG-1 and ATPTOG-4 to determine whether the AgA sorbent retained tritium.

\section{MATERIALS AND METHODS}

The experimental methodology for the tests was reported previously in Jubin et al. (2017). The specific details of the experiments and any deviations from the proposed methodology are discussed below. Five tests were conducted utilizing the experimental setup shown in Figures 1 and 2 with conditions presented in Table 1. 


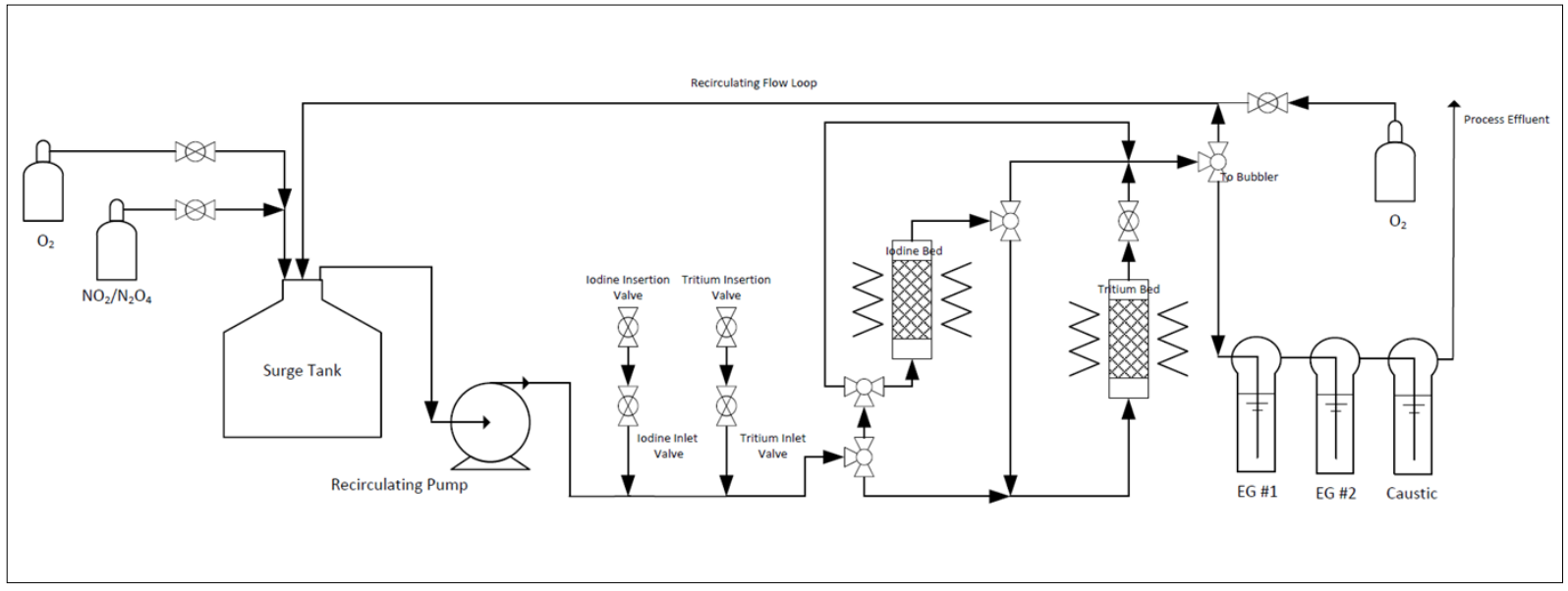

Figure 1: Schematic of iodine and tritium sorbent test system.

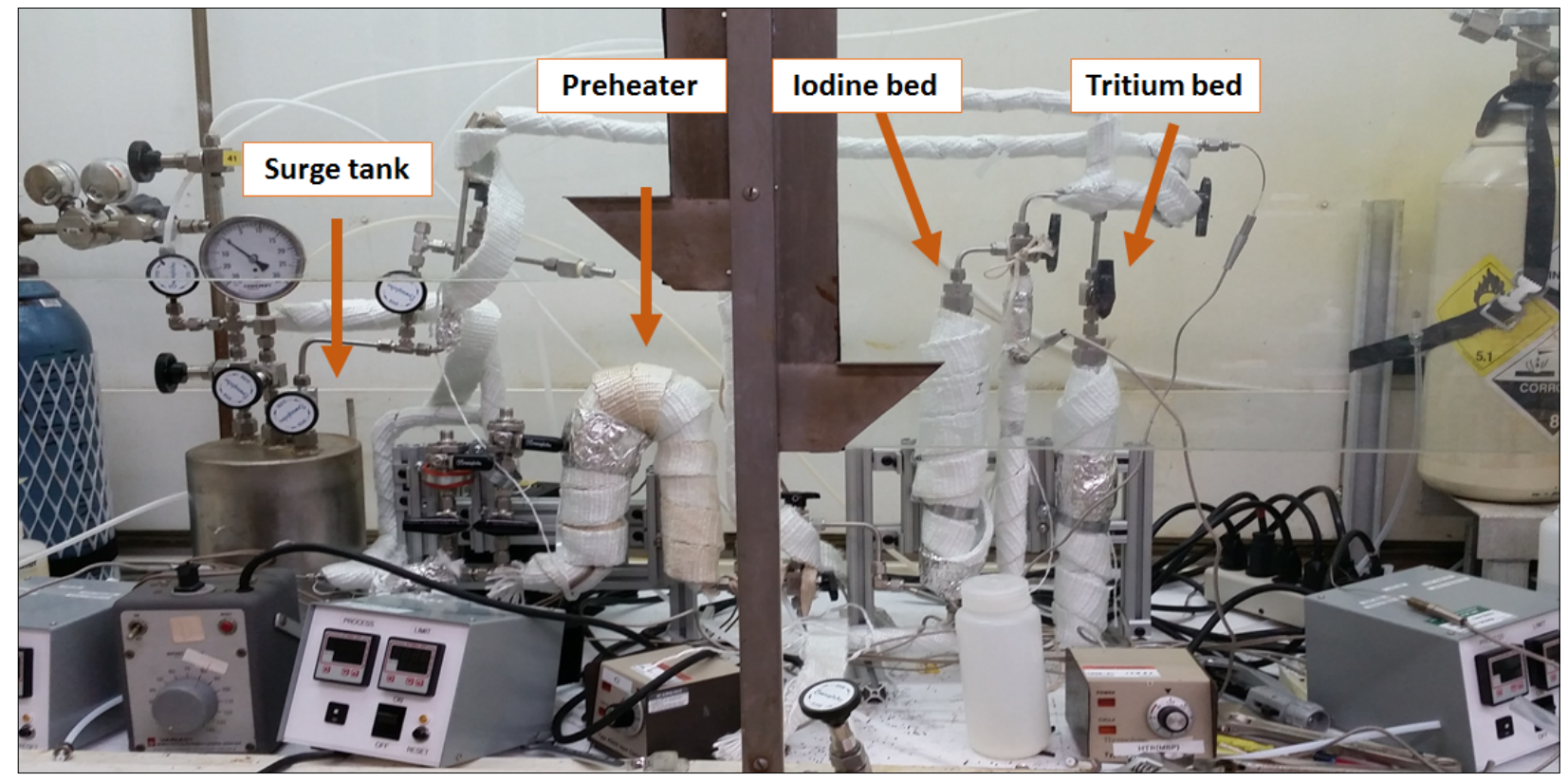

Figure 2: Photograph of iodine and tritium sorbent test system.

\subsection{Materials}

The system was primarily constructed of stainless steel components. The surge tank was legacy equipment and had previously been exposed to $\mathrm{NO}_{2}, \mathrm{O}_{2}$, inert gases, and some uranium. The $\mathrm{NO}_{2}$ and $\mathrm{O}_{2}$ feed lines were Teflon, and the discharge connection between the stainless test system and the liquid scrubbers was Teflon.

Prior to the start of each test, the iodine column was loaded with AgA prepared at ORNL. This material was prepared by combining $500 \mathrm{~g}$ of $1.18-1.40 \mathrm{~mm}$ diameter activated alumina desiccant spheres (Sorbent Technologies) with $380 \mathrm{~mL}$ of $1.936 \mathrm{M} \mathrm{AgNO}_{3}$ solution. This solution was heated to a maximum temperature of $125^{\circ} \mathrm{C}$ for 9 hours under vacuum. After completion of this process, the alumina spheres weighed $653.3 \mathrm{~g}$. The column is separated into discrete segments with layers of quartz wool between the segments. The length of the iodine bed is $10 \mathrm{~cm}$. The tritium column contained silica gel or 3A MS, both approximately $6-12$ mesh size, with a bed depth of $10 \mathrm{~cm}$. 


\subsection{Establishment of Recirculation Loop and lodine Capture Phase}

The recirculation system was closed off to the environment, evacuated to an absolute pressure of $0.30 \mathrm{~atm}$, and held to determine whether the system was leak tight. After determination of the leak rate (observably leak tight for the experimental durations), $\mathrm{NO}_{2}$ was delivered to the system from a tank of liquid $\mathrm{N}_{2} \mathrm{O}_{4}$ until the system pressure was raised to $\sim 0.83 \mathrm{~atm}$ and oxygen was added until the final pressure of the system was $\sim 1.14 \mathrm{~atm}$. This resulted in a total system $\mathrm{NO}_{2}$ partial pressure of $0.53 \mathrm{~atm}$ and an $\mathrm{NO}_{2}$ concentration of $47 \%$ in the gas phase.

After addition of the $\mathrm{NO}_{2}$ and $\mathrm{O}_{2}$, the recirculation pump was activated. The system flow path (Figure 3) was set so that gas flow would recirculate through the iodine bed (which contained $\sim 30 \mathrm{~g}$ of AgA in all but test ATPTOG-5) and surge tank. The total pressure of the system dropped during the establishment of the recirculation loop such that the gas loop was at sub-atmospheric pressure prior to the introduction of iodine and tritium. This pressure drop may be due to the consumption of gaseous components by system materials or sorbent material.

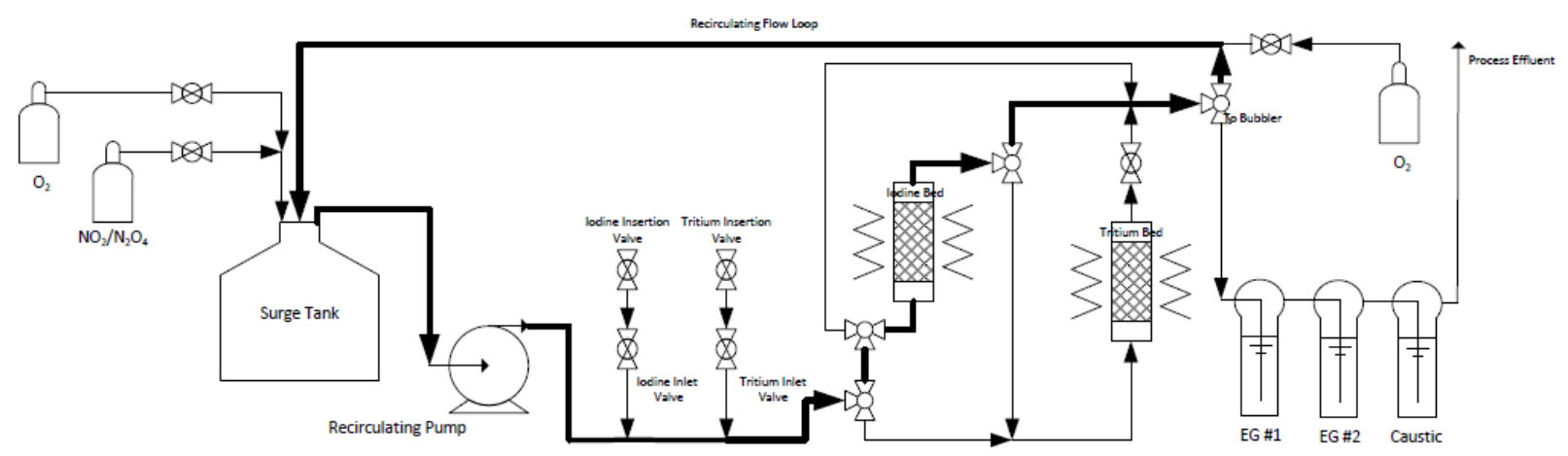

Figure 3: Gas flow path (bolded) during iodine capture phase.

The tritium bed was bypassed during recirculation. Heat tapes were placed on the main recirculation lines, the iodine bed, and the tritium bed; the surge tank was not heated. The heat tapes were activated after recirculation was initiated. There were three primary heating zones: a "hot zone" designed to simulate the reactor in an advanced TPT system with a setpoint of $300^{\circ} \mathrm{C}$; the iodine bed with a setpoint of $150^{\circ} \mathrm{C}$; and the process lines, which were heated to achieve temperatures $>40^{\circ} \mathrm{C}$. The gas was recirculated to allow heating and to expose the sorbent bed to the gas stream. During recirculation, the pressure of the system dropped by $\sim 0.30 \mathrm{~atm}$.

A short time after beginning recirculation ( $10 \mathrm{~min}), 100 \mu \mathrm{L}$ of tritiated water was added to the system, corresponding to a total activity of $100 \mu \mathrm{Ci}$. About 2 hours after the addition of tritium, $0.13 \mathrm{~g}$ iodine was added (Tests 2 and 3 only). Recirculation continued for $2-4$ hours.

\subsection{Tritium Capture (TC) Phase}

After iodine capture and recirculation, the heat tapes and recirculation pump were turned off and the tritium bed was heated to $40^{\circ} \mathrm{C}$. The flow path was altered so that the gas stream would not pass through the iodine bed but would pass through the tritium bed and then pass out of the system through bubblers of ethylene glycol and/or sodium hydroxide $(\mathrm{NaOH})$, as shown in Figure 4. To ensure that the tritium-bearing gas stream was fully discharged through the scrubbers, oxygen was added to the system to reach a pressure of $3.0 \mathrm{~atm}$ and bled down through the tritium bed and bubblers to $\sim 1.1 \mathrm{~atm}$. The system was successively pressurized and depressurized five times, resulting in a final nominal $\mathrm{NO}_{2}$ concentration of $\sim 0.34 \%$ from an initial nominal concentration of $47 \%$. These pressurization/depressurization cycles should result in 
$>99 \%$ of the gas-phase tritium being discharged through the tritium bed and into the ethylene glycol and $\mathrm{NaOH}$ scrubbers. Any tritium adsorbed by the solid sorbents would remain in the system.

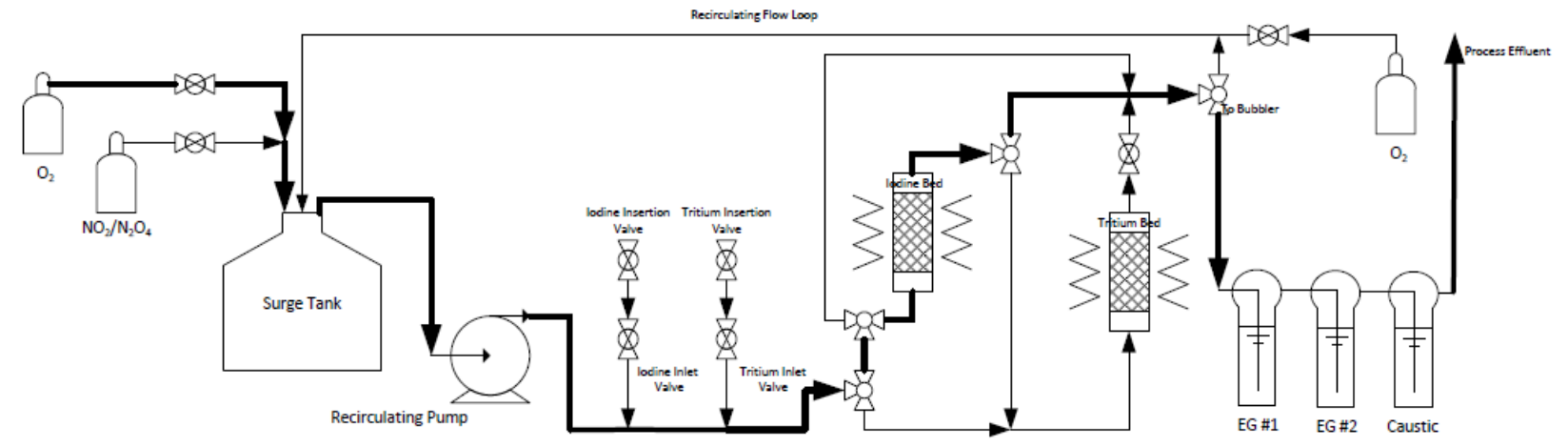

Figure 4: Gas flow path (bolded) during tritium capture phase.

\subsection{Tritium Sorbent Regeneration (TR) Phase}

The system was then sealed off, and the temperature of the tritium bed was raised to the selected regeneration temperature. After reaching the setpoint, the system was opened, and the bed was purged with oxygen at 0.5 liters per minute (LPM) for 2 hours. The effluent from the tritium column was flowed in series through two ethylene glycol scrubbers and one $\mathrm{NaOH}$ scrubber, with the scrubber solutions replaced between the TC and TR phases of testing. The flow path for the oxygen purge is shown in Figure 5.

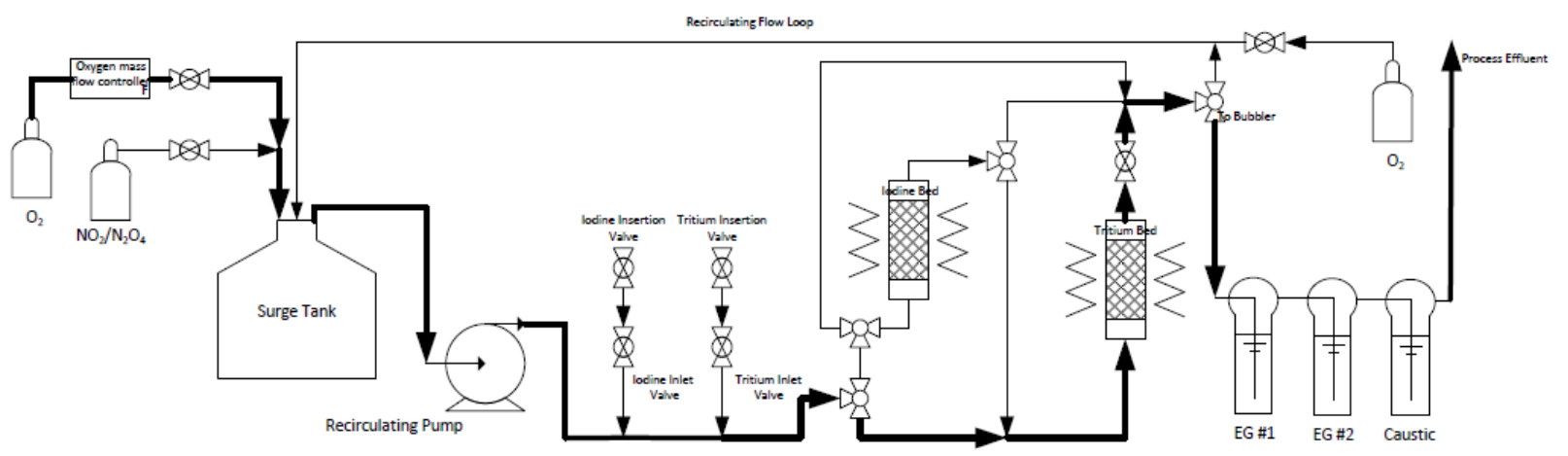

Figure 5: Gas flow path (bolded) during tritium regeneration phase.

\section{5 lodine Sorbent Purge (IP)}

Upon completion of tritium regeneration, the system valving alignment was modified so that the tritium column was sealed from the rest of the system, and the iodine column was included in the flow path (Figure 6). The iodine column was held at $150^{\circ} \mathrm{C}$ and purged with oxygen at $0.5 \mathrm{LPM}$ for 2 hours. The effluent was passed through one ethylene glycol and one $\mathrm{NaOH}$ scrubber, with the scrubber solutions replaced between the TR and IP phases of testing. 


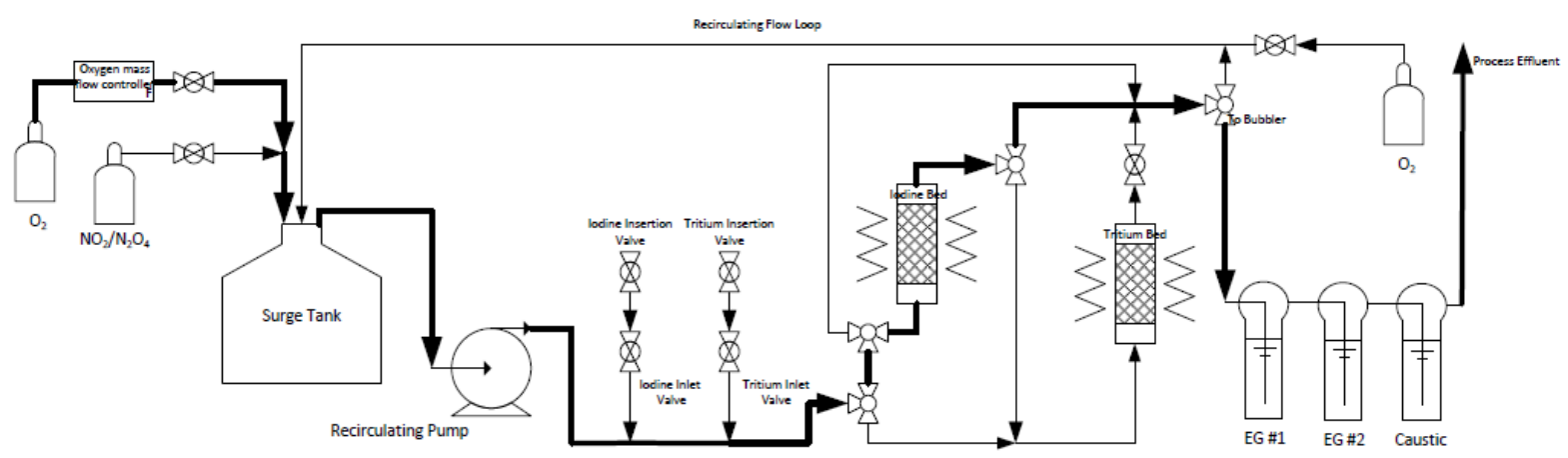

Figure 6: Gas flow path (bolded) during iodine sorbent purge phase.

\subsection{Analysis}

The tritium content of the ethylene glycol and $\mathrm{NaOH}$ scrubbers were determined by liquid scintillation counting (LSC). Tritium determination on both iodine and tritium solid sorbents was performed by placing $\sim 1 \mathrm{~g}$ of the sorbent into a liquid scintillation cocktail and counting the resulting solution. The iodine content of each scrubber was determined by inductively coupled plasma-mass spectrometry (ICP-MS). The iodine content of the iodine and tritium sorbents was determined by neutron activation analysis (NAA) performed using ORNL's High Flux Isotope Reactor.

\section{RESULTS}

Five experiments were completed. The total tritium and iodine recoveries for each test are shown in Table 2. The iodine recovery is based on the total amount of iodine recovered in both the sorbent (analyzed by NAA) and the liquid scrubbers (analyzed by ICP-MS). The tritium recovery includes the amount of tritium found in the liquid scrubbers only. Both the tritium and iodine sorbents were counted upon conclusion of the experiment by LSC but given the potential for self-shielding of the weak beta emitter by the solids, these numbers can only be considered qualitative.

Table 2: Tritium and iodine recovered from ATPTOG test system.

\begin{tabular}{|c|c|c|c|c|c|c|}
\hline Test \# & $\begin{array}{c}\text { Tritium } \\
\text { sorbent }\end{array}$ & $\begin{array}{c}\text { Iodine } \\
\text { sorbent }\end{array}$ & $\begin{array}{c}\text { Liquid scrubber } \\
\text { tritium recovery } \\
\mathbf{( \% )}\end{array}$ & $\begin{array}{c}\text { Tritium } \\
\text { on AgA }\end{array}$ & $\begin{array}{c}\text { Tritium on } \\
\text { silica or } \\
\text { 3A MS }\end{array}$ & $\begin{array}{c}\text { Total iodine } \\
\text { recovery } \\
(\%)\end{array}$ \\
\hline 1 & None & $\mathrm{AgA}$ & 6.2 & Yes & $\mathrm{n} / \mathrm{a}$ & $\mathrm{N} / \mathrm{A}$ \\
\hline 2 & Silica gel & $\mathrm{AgA}$ & 2.0 & Yes & Yes & $0.4 \%$ \\
\hline 3 & $3 \mathrm{~A}$ MS & $\mathrm{AgA}$ & 3.6 & Yes & Yes & $30.2 \%$ \\
\hline 4 & None & $\mathrm{AgA}$ & 5.4 & Yes & $\mathrm{n} / \mathrm{a}$ & $\mathrm{N} / \mathrm{A}$ \\
\hline 5 & None & None & 3.8 & $\mathrm{n} / \mathrm{a}$ & $\mathrm{n} / \mathrm{a}$ & $\mathrm{N} / \mathrm{A}$ \\
\hline
\end{tabular}

\section{1 lodine Distribution}

The AgA sorbent changed color during the course of testing, from an initial grey color to ivory or white upon test conclusion. Tests ATPTOG-2 and -3 displayed markedly different iodine recoveries, with only $0.4 \%$ of the $\sim 0.13 \mathrm{~g}$ delivered recovered on the iodine sorbent or in the liquid scrubbers for Test -2 , and $30.2 \%$ recovered in Test -3 . The distribution of iodine in the bed segments is shown in Tables 3 and 4 . Of the iodine recovered, the majority was found on the AgA sorbent, with $<1 \mathrm{mg}$ located in scrubbing liquids. The first AgA segment in Test 2 contained $<0.02 \mathrm{mg} \mathrm{I} / \mathrm{g}$ sorbent, with no other segments above the 
detection limit. In the case of Test 3 , the recovered iodine was located on the first bed segment analyzed (5 mg/g sorbent), with subsequent segments displaying loadings of $<1 \mathrm{mg} / \mathrm{g}$ sorbent.

Table 3: Iodine distribution between AgA bed segments and liquid scrubbers, Test 2

\begin{tabular}{|l|l|l|l|l|}
\hline \multicolumn{1}{|c|}{ Sample ID } & \multicolumn{1}{|c|}{$\begin{array}{c}\text { Bed segment mass } \\
(\mathbf{g})\end{array}$} & $\begin{array}{c}\text { Iodine } \\
\text { (mg/g sorbent) }\end{array}$ & $\begin{array}{c}\text { Uncertainty } \\
\text { (mg/g sorbent) }\end{array}$ & \multicolumn{1}{|c|}{$\begin{array}{c}\text { Iodine } \\
\text { recovered } \\
\text { (\%) }\end{array}$} \\
\hline R2-AgA1 & 5.2643 & 0.0172 & 0.0001 & $<0.1$ \\
\hline R2-AgA2 & 5.0465 & MDA & - & - \\
\hline R2-AgA3 & 4.9000 & MDA & - & - \\
\hline R2-AgA4 & 5.2317 & MDA & - & - \\
\hline R2-AgA5 & 5.0229 & MDA & - & - \\
\hline Liquid scrubbers & & & & 0.4 \\
\hline MDA $=$ below minimum detectable activity & & \\
\hline
\end{tabular}

Table 4: Iodine distribution between AgA bed segments and liquid scrubbers, Test 3

\begin{tabular}{|l|l|l|l|l|}
\hline \multicolumn{1}{|c|}{ Sample ID } & \multicolumn{1}{|c|}{$\begin{array}{c}\text { Bed segment mass } \\
(\mathbf{g})\end{array}$} & $\begin{array}{c}\text { Iodine } \\
(\mathbf{m g} / \mathbf{g} \text { sorbent) }\end{array}$ & \multicolumn{1}{|c|}{$\begin{array}{c}\text { Uncertainty } \\
(\mathbf{m g} / \mathbf{g} \text { sorbent) }\end{array}$} & $\begin{array}{c}\text { Iodine recovered } \\
\mathbf{( \% )}\end{array}$ \\
\hline R3-AgA1 & 6.3215 & 5.9400 & 0.0297 & 27.6 \\
\hline R3-AgA2 & 5.3908 & 0.5115 & 0.0026 & 2.0 \\
\hline R3-AgA3 & 5.4881 & MDA & - & - \\
\hline R3-AgA4 & 5.485 & 0.0087 & 0.0000 & $<0.1$ \\
\hline R3-AgA5 & 4.4879 & MDA & - & 0.6 \\
\hline Liquid scrubbers & & & \\
\hline MDA $=$ below minimum detectable activity & \\
\hline
\end{tabular}

\subsection{Tritium Distribution}

The distribution of tritium within the ethylene glycol and $\mathrm{NaOH}$ scrubbers is shown in Table 5. The designators TC, TR, and IP refer to the tritium capture, tritium sorbent regeneration, and iodine sorbent purge stages, respectively.

The maximum observed tritium recovery was $6.2 \%$ of the $100 \mathrm{mCi}$ delivered to the system per test. There was observable tritium present on both the $\mathrm{AgA}$ and $3 \mathrm{~A} \mathrm{MS} /$ silica gel at the conclusion of each test, even following regeneration and/or purging of both sorbents. 
Table 5: Tritium distribution in liquid scrubbers

\begin{tabular}{|c|c|c|c|c|c|c|}
\hline \multirow[b]{2}{*}{ Scrubber designation } & \multirow{2}{*}{ Scrubber liquid } & & \multicolumn{4}{|c|}{ Total tritium recovery in scrubber $(\%)$} \\
\hline & & Test 1 & Test 2 & Test 3 & Test 4 & Test 5 \\
\hline TC1 & Ethylene glycol & 0.114 & 0.1 & 0.132 & 0.292 & 3.803 \\
\hline TC2 & Ethylene glycol & MDA & MDA & 0.002 & MDA & MDA \\
\hline TC3 & $\mathrm{NaOH}$ & $n / a$ & $n / a$ & 0.005 & MDA & 0.003 \\
\hline TR1 & Ethylene glycol & 3.787 & 0.93 & 2.765 & 4.088 & \multirow{5}{*}{$n / a$} \\
\hline TR2 & Ethylene glycol & MDA & MDA & MDA & MDA & \\
\hline TR3 & $\mathrm{NaOH}$ & $n / a$ & MDA & MDA & 0.005 & \\
\hline IP1 & Ethylene glycol & 2.256 & 0.91 & 0.737 & 0.828 & \\
\hline \multirow[t]{3}{*}{ IP2 } & $\mathrm{NaOH}$ & $n / a$ & 0.07 & MDA & 0.142 & \\
\hline & SUM & $6.2 \%$ & $2.0 \%$ & $3.6 \%$ & $5.4 \%$ & $3.8 \%$ \\
\hline & \multicolumn{6}{|c|}{$\begin{array}{l}M D A=\text { below minimum detectable activity } \\
n / a=\text { scrubber not included in test }\end{array}$} \\
\hline
\end{tabular}

Given the low overall recoveries of tritium from the ATPTOG system, only limited conclusions can be made based on the tritium content of the scrubbers. The amount of tritium in the gaseous effluent during the tritium capture phase is of the same magnitude regardless of whether a tritium sorbent is present. However, the total amount of tritium released during the tritium regeneration phase is lower with a tritium sorbent present, and there is some residual tritium on the solid sorbents at the conclusion of each test. This indicates some interaction of tritium with the sorbent even in the presence of $\mathrm{NO}_{2}$.

Given that residual tritium was located on $\mathrm{AgA}$ at the conclusion of each test, there is also indication that tritium is interacting with the iodine sorbent. The magnitude of this interaction was not quantified during testing, as tritium analysis of solids is analytically complex. Some of the tritium on the sorbent was desorbed during the iodine purge step, in which the column was held at $150^{\circ} \mathrm{C}$, and dry gas was passed through the column for 2 hours. An unknown fraction was retained by the sorbent.

\section{SYSTEM DISASSEMBLY}

The low tritium and iodine recoveries, along with confirmation by pressure test that the system was leak tight, prompted a full system disassembly to assess whether there was holdup of tritium and iodine within the system. Smears were taken at multiple points in the system. It was found that the surge tank within the system was corroded and smeared positive for tritium at multiple locations. Several corroded fittings were removed from the surge tank, and both iodine and tritium were found in the corrosion products. No corrosion was observed at other visually inspected locations, and no other inspected locations smeared positive for tritium.

During system disassembly, substantial $\mathrm{NO}_{2}$ holdup was found within the surge tank, as the tank offgassed characteristic brown $\mathrm{NO}_{2}$ gas for at least 2 weeks following system disassembly. The surge tank was not heated, and it is possible that there was some condensation of $\mathrm{NO}_{2}$ gas within the tank.

The recirculation loop was structured such that the iodine-bearing gas stream encountered the alumina sorbent bed prior to the surge tank. System disassembly showed no corrosion in the portion of the system between the iodine introduction port and the iodine sorbent column. Given these details, it was concluded 
that the measured iodine content of the sorbent could be representative of a single-pass iodine sorbent column within a ATPTOG treatment system.

\section{CONCLUSIONS}

Given the extent of corrosion observed in the surge tank and the confirmed presence of iodine and tritium within the corrosion products, the low tritium and iodine recoveries observed during testing are unsurprising. Although the surge tank was constructed of stainless steel, which is considered to be compatible with $\mathrm{NO}_{2}$ gas and $\mathrm{N}_{2} \mathrm{O}_{4}$ liquid, the materials of construction for an ATPTOG treatment system should be carefully reconsidered. Iodine is known to corrode stainless steel in the presence of water. A second possibility is that $\mathrm{NO}_{2}$ itself contributed to the corrosion of the system, either as a liquid $\left(\mathrm{N}_{2} \mathrm{O}_{4}\right)$ or a gas. The surge tank, which was the only visibly corroded component, was not heated during testing.

The low tritium recoveries prevented quantitative conclusions regarding the adsorption of tritium by either silica gel or $3 \mathrm{~A}$ MS in high $\mathrm{NO}_{2}$ systems. Tritium was observed on the sorbent at the conclusion of the tritium sorbent regeneration step. Tritium was found to interact with the iodine sorbent, AgA, to an unknown extent. Tritium was also found in the effluent of the AgA purge and on the solid sorbent following the completion of the sorbent purge.

Although the final iodine content of the AgA sorbent varied significantly during Runs 2 and 3, the ability of $\mathrm{AgA}$ to adsorb iodine in the presence of high levels of $\mathrm{NO}_{2}$ appears to be substantially reduced upon exposure of the sorbent to $\mathrm{NO}_{2}$. The sorbent was contacted with $\mathrm{NO}_{2}$ for 2 hours prior to the introduction of iodine, and even this limited exposure resulted in an observable decrease in iodine capacity. The replicate testing showed iodine recoveries on the sorbent of $<0.1 \%$ (Run 2 ) and $30.2 \%$ (Run 3). Given the difficulties observed regarding the materials of construction used for this testing and the difference in sorbent loading of Runs 2 and 3, the performance of the AgA should be reexamined with a more robust system. These initial tests, however, do indicate a failure of the sorbent to perform to the levels that would be required in a ATPTOG treatment system.

This testing leaves many fundamental questions regarding the ATPTOG iodine and tritium abatement systems unanswered. Some of the most critical include the following.

- What is the total iodine capture capacity of AgA if operated with a recirculating gas stream?

- To what extent does tritium co-adsorb on the AgA sorbent?

- To what extent can 3A MS and silica gel retain tritium from an ATPTOG bleed stream?

- Can the tritium retained on 3A MS and silica gel be desorbed quantitatively?

These questions, and others not listed, indicate that tritium and iodine abatement from an ATPTOG stream by solid sorbents is currently at a low stage of technological development and that deployment of such an abatement system would require substantial additional research and development. It is unknown what currently available solid sorbent technology is able to withstand degradation from high concentrations of corrosive $\mathrm{NO}_{2}$ and $\mathrm{I}_{2}$ gas.

\section{REFERENCES}

Johnson, J. A. and G. D. DelCul. 2016. "Reaction System Design for $\mathrm{NO}_{2}$ Oxidation of Used Nuclear Fuel for the FY17 Hot Test," ORNL/LTR-2016/355, Oak Ridge National Laboratory, Oak Ridge, TN. 
Jordan, J. A. and R. T. Jubin. 2017. Stability of Tritium and Iodine Sorbents under Tritium-Pretreatment Off-Gas Conditions, ORNL/SR-2017/162, also NTRD-MRWFD-2017-000411, UT-Battelle LLC, Oak Ridge National Laboratory, Oak Ridge, TN.

Jubin, R. T., N. R. Soelberg, D. M. Strachan, and G. Ilas. 2012. Fuel Age Impacts on Gaseous Fission Product Capture during Separations, Report No. FCRD-SWF-2012-000089, UT-Battelle, LLC, Oak Ridge National Laboratory, Oak Ridge, TN.

Jubin, R. T., S. H. Bruffey, J. A. Jordan, and G. D. DelCul. 2017. Assembly and Testing of a Tritium and Iodine Removal System for Use with Advanced Tritium Pretreatment, ORNL/TM-2017/464, also NTRDMRWFD-2017-000157, UT-Battelle LLC, Oak Ridge National Laboratory, Oak Ridge, TN.

Spencer, B. B., S. H. Bruffey, J. A. Jordan, and R. T. Jubin. 2017. Design of a Tritium and Iodine Removal System for Use with Advanced Tritium Pretreatment, ORNL/SR-2017/116, also NTRD-MRWFD-2017000311, UT-Battelle LLC, Oak Ridge National Laboratory, Oak Ridge, TN. 